Review

\title{
(Mis)Reading Muslims and Multiculturalism
}

Peter Kivisto ${ }^{1,2}$

${ }^{1}$ Sociology Department, Augustana College, Rock Island, IL 61201, USA; E-Mail: peterkivisto@augustana.edu

${ }^{2}$ Department of General History, University of Turku, 20014 Turku, Finland

\section{How to Cite this Article}

Kivisto, P. (2013). (Mis)Reading Muslims and Multiculturalism. Social Inclusion, 1(2), 126-135.

\section{Acknowledgement}

This Review was published by Librello, Social Inclusion's former publisher.

\author{
About the Journal \\ sion worldwide. \\ www.cogitatiopress.com/socialinclusion \\ Editor-in-Chief \\ Professor Ulf R. Hedetoft, Faculty of Humanities, University of Copenhagen, Denmark \\ Managing Editor \\ Mr. António Vieira, Social Inclusion, Cogitatio Press, Portugal
}

Social Inclusion is a peer-reviewed open access journal which provides academics and policy-makers with a forum to discuss and promote a more socially inclusive society. The journal encourages researchers to publish their results on topics concerning social and cultural cohesiveness, marginalized social groups, social stratification, minority-majority interaction, cultural diversity, national identity, and core-periphery relations, while making significant contributions to the understanding and enhancement of social inclu- 


\title{
(Mis)Reading Muslims and Multiculturalism
}

\author{
Peter Kivisto ${ }^{1,2}$ \\ ${ }^{1}$ Sociology Department, Augustana College, Rock Island, IL 61201, USA; E-Mail: peterkivisto@augustana.edu \\ ${ }^{2}$ Department of General History, University of Turku, 20014 Turku, Finland
}

Submitted: 22 August 2013 | In revised form: 1 October 2013 | Accepted: 26 November 2013 |

Published: 5 December 2013

\begin{abstract}
This paper offers a review and conceptual reflection on fears about the Muslim presence and lack of inclusion into Western European societies and the core features of criticisms of multiculturalism. It does so by first addressing the misreadings of Islam and multiculturalism in influential works by Christopher Caldwell and Paul Scheffer. It then addresses the main points of their critiques by examining the role of the state in Muslim incorporation, framing multiculturalism theoretically in terms of claims-making, and offering evidence of the ways in which Muslim claims-making has occurred.
\end{abstract}

Keywords: claims-making; exclusion; multiculturalism; Muslims; social inclusion

\section{Introduction}

How should one read perceptions of the Islamic presence on European soil? More specifically, how should one respond to the arguments that Islam is incompatible with liberal democracy and that multiculturalism prevents, or at least inhibits integration? This review is intended to offer alternative views to those positions. It does so by first questioning the essence of the arguments advanced by two sophisticated public intellectuals -Christopher Caldwell and Paul Scheffer-before moving on to sketching that alternative.

If an observer looks at the ways Muslims were generally depicted in the 1980s, the foci of concern were often riveted more on the socioeconomic location and the ethnic or national origins of the immigrants than on religion. Writing at that time, William Safran compared Muslims in the late twentieth century to Jews a century or so earlier. He noted that unlike Jews, Muslims did not have to contend with the charge of being a Christ-killer or with the idea of a being perpetually homeless people. Safran went on to assert that, "Islam seems too exotic to native Europeans, and the presence of its adherents in Germany and France is too recent, for the majority and for the leaders of the Christian establishment to have developed a distinct theological hostility or a mass paranoia about Islam or Muslims". At the same time, whereas Jews proved to rather quickly improve their economic circumstances, Muslims have had a much more difficult time gaining an economic foothold. The factors contributing to this include discrimination, low educational levels, and the impact of traditionalist ethnic cultures which, for example, encourages large families. It also includes religion, with questions being raised about the compatibility of Islam and modern, largely secular Western societies. Nonetheless, Safran was convinced that "religion is a far less significant source of tension and hostility for postwar Muslim immigrants than it was for prewar Jewish immigrants" ([1], p. 106). 
That assessment was soon to be revisited. The turning point was the Rushdie Affair. The $9 / 11$ attacks, followed by the terrorist bombing in Madrid in 2004, the murder of Theo van Gogh in Amsterdam the same year, and both the bombings in London and the Danish cartoon controversy the following year resulted in a reevaluation of the significance of religion as Islam was increasingly perceived to be a threat to security. Certainly for many ordinary citizens these events appeared to offer convincing evidence that there was a problem with Islam's presumed incompatibility with European liberal values. These perceptions did not spring from nowhere, but rather emerged out of historically-rooted antipathies toward Islam, seen in the rhetoric of invasion, that, for example, draw a contemporary parallel with the siege of Vienna.

That the reality is considerably more complex can be seen in the analysis of Jytte Klausen of the last of these events, the publication in the Danish newspaper Jyllands-Posten of a dozen cartoons depicting the Prophet Muhammad. The publication resulted in protests by Muslims in Denmark and other European countries against the newspaper and the Danish government, and rioting in numerous Muslim nations. While some were quick to see these protests as spontaneous outbursts reflective of the clash of civilizations, Klausen argues that this overlooks the political dimension to the conflict, which involved, among other things, the provocative actions of the Egyptian government (the pre-Arab Spring Mubarak government) as it sought to curry favor with the Muslim Brotherhood and with similar domestic political considerations in several other Muslim nations [2].

It is often difficult to disentangle the sources of anti-immigration animus. On the one hand, immigrants qua immigrants are often the object of hostility. They can be seen as competitive threats and economic burdens to the receiving society, as well as being in various ways perceived to be culturally "different" in negative terms. Thus, findings from the Eurobarometer in the early years of the twenty-first century found that one in five Europeans in 15 countries surveyed believed that their nation should enact repatriation policies for legal migrants, while four out of ten interviewees expressed opposition to the granting of civil rights to legal migrants [3]. The difficulty arises when trying to determine the precise impact of economic versus cultural factors. As an illustration, Thomas Pettigrew noted near the end of the past century that there is "less French prejudice against Asians than North Africans and less Dutch prejudice against Surinamers than Turks" ([4], p. 84). Is this due to the higher human capital levels of Asians versus North Africans and because of the colonial connection with immigrants from Suriname and the lack thereof with Turks? Or is it because Asians and Surinamers are not Muslim, while North Africans and Turks are? Or is there some other reason for these differences?

It is precisely the need to answer these questions that has led to a growing literature on Islamophobia. Erik Bleich noted that the term appeared on the scene in the late 1990s, used polemically by political activists and commentators. He contends that it entered into the realm of a social science concept with a 1997 study funded by the Runnymede Trust on the impact that Islamophobia was having on British race relations. Despite its problematic provenance, he concludes that it is better to maintain the term and shape it into a useful analytical tool rather than, as some have suggested, abandoning it. He does so by defining it as "indiscriminate negative attitudes or emotions directed at Islam or Muslims" ([5], p. 1582), thereby making it part of the subset of concepts used to study intolerance.

Reviewing various polling sources in two countries, Britain and France, Bleich concluded that over a two decade period running from 1988 to 2008, anti-Muslim prejudice rose in both countries and that compared to other religious groups, Muslims are viewed with considerable suspicion. They have, in short, moved downward on the ethno-racial hierarchy. However, they have not landed on the bottom, for there are some ethnic groups that fare worse. These include Asians and Arabs, which given that these ethnic categories overlap considerably with Islam, reveals the dual-edged character of xenophobia. The group that was consistently located at the bottom of the hierarchy is the Romawhich is probably little consolation for Muslims [6].

During this time period, right-wing extremist groups have proliferated and radical right political parties have seen their fortunes rise in the polls. Three of the latter stand out for their electoral success: the Austria Freedom Party, the Danish People's Party, and the Swiss People's Party. These and other right-wing parties are not alike in all respects. What they share in common, according to Cas Mudde, is the way they frame debates over immigration issues in terms of "two main themes: a cultural threat (recently amalgamated as a culturalreligious threat) and a security threat (recently amalgamated as a criminal-terrorist threat). Secondary themes include economic competition and an antielite/anti-politics narrative" ([7], p. 31).

These themes are not confined to the radical right. Indeed, the idea that Islamic values and practices are incapable of fitting into modern European culture is a theme that one can find across the political spectrum. Muslims are perceived to be a problem because they are viewed as incapable of becoming truly integrated into Europe. Instead, they are seen as transplanting their worldview onto European soil. Seen in conspiratorial terms, whereby Muslims are engaged in a concerted effort to dominate Europe demographically and culturally, this is depicted as the emergence of "Eurabia". Stressing the paranoid character of such thinking and the parallel to the anti-Semitism of a century earlier, Nasar Meer dubs this "the protocols of Eurabia", and points to intellectuals such as Orianna Fallaci, Thilo Sarrazin, and Niall Ferguson who have trafficked in these ideas ([8], pp. 391, 393). We turn to one representative 
example below, Christopher Caldwell, whom John Bowen has described as "the most knowledgeable of the recent European-Islamic threat writers" ([9], p. 51).

\section{Misreading Islam in Europe}

The argument is simply stated: the barrier to the incorporation of new immigrants in contemporary Europe is religion, or to be more precise, Islam. Given a relatively small Muslim population that contains a substantial upwardly mobile segment in the United States, along with that nation's history of accommodating religious pluralism, it is not surprising that for those who voice concerns about the erosion of a distinct form of American identity, Islam does not loom large from their perspective as a source of the problem. This stands in stark contrast to Western Europe today, as Christopher Caldwell's Reflections on the Revolution in Europe attests [10]. His is a far-ranging book that strives hard to appear impartial, but a passage in which he expresses sympathy for the message of Enoch Powell's "rivers of blood" speech and Norman Tebbit's cricket test of national loyalty is revealing ([10], pp. 147-148).

Caldwell's book can be seen as in many respects parallel to Samuel Huntington's Who Are We? The Challenges to America's National Identity [11]. Caldwell is not concerned with Turkish guest workers in Germany per se, nor is he concerned with Algerians in France or Pakistanis in Britain. Rather, he is concerned with Muslims in Christian Europe - with a further qualification that Christian Europe has become an increasingly secular Europe. That being said, he realizes that Turks were welcomed into Germany in the post-war reconstruction period as guest workers essential to helping the nation by remedying severe labor shortages. The intergovernmental arrangements that defined the German guest worker policies viewed these laborers as temporary sojourners who would, when their services were no longer needed, return home. As such, there was no need to raise issues about integration. Germans had invited Turks in and because they had done so, they had an obligation to be hospitable to their guests. However, the guests have a reciprocal obligation, which is to refuse to transform themselves into Simmel's stranger, the person "who comes today and stays tomorrow". In this regard, Caldwell quotes approvingly Hans Magnus Enzensberger's assertion that, "the guest is sacred, but he may not tarry". From his perspective, Algerians in France and Pakistanis in Britain are in this regard no different than Turks in Germany ([10], p. 71). Neither Caldwell nor Enzensberger note that the sacred guest is an ambiguous presence even before tarrying, as George Bataille's idea of the sacred being at once sacred and profane would suggest [12].

Immigration in contemporary Europe is perceived to be a significant problem. In an especially revealing section of the book titled "Civilization and Decadence", Caldwell warns that "'advanced' cultures have a long track record of underestimating their vulnerability to 'primitive' ones" ([10], p. 20). Placing the words "advanced" and "primitive" in quotation marks is an indication of an ambivalence running through the text. On the one hand, Caldwell characterizes Islam as the product of a great world civilization, but on the other hand its adherents in Europe are in some unspecified way less developed than their European counterparts and a clear and present danger to the continent.

Part of the book addresses issues of marginalization, self-segregation, poverty, and the social problems associated with ghetto life. However, it becomes clear that the crux of the problem does not rest at this level, but precisely at the higher level of cultural structures. Why is Islam a problem? Caldwell argues that it is because taken as either religion or culture, it cannot be squared with the religious tradition and culture of Europe, which has in the contemporary context increasingly been defined in terms of a secular, or one might say post-Christian worldview. Islam is a "hyper-identity", and in the European context it constitutes an "adversary culture" ([10], pp. 158$162,171-173)$. What this means for Muslim immigrants is that they have two options: to remain a Muslim and thereby an outsider-the perpetual Other-or to abandon Islam in order to become a European. Caldwell is convinced that there is no third way. His contends that Muslims are opting to maintain their inherited culture; the result is that immigration "is not enhancing or validating European culture, it is supplanting it" ([10], p. 20).

Caldwell believes that a factor contributing to Muslim resistance to becoming European is that multiculturalism's spokespersons have encouraged them to preserve their cultural heritages while disparaging all that is European. He writes that, "by now it is almost second nature for Westerners to assume that anything familiar, traditional, and Western is to be opposed; and anything discomfort-inducing and foreign to be protected". The result, Caldwell wrote in a subsequent essay, amounts to the Islamic "colonization" of European territory. He describes what he means in the following passage:

But there is a more important reason [than mere demographic accounts] why "colonization" well describes the influx of the past half-century. It is that the terms governing this transformation are set by the immigrants and not by the natives, who started off not caring, and wound up not daring, to impose too many rules on their new neighbors" ([10], p. 31).

The problem is that Muslims take their culture seriously, while Europeans no longer hold deeply-held convictions, especially about religion. In making such a claim, Caldwell implicitly raises three questions: (1) have states actually been as ineffectual as his account would suggest in applying existing laws concerning church-state relations to new circumstances?; (2) what is multiculturalism?; and (3) has there been no success in integrating Muslims into the public sphere? 
Each question will be addressed in the second part of this paper, after first examining the misreading of multiculturalism.

\section{The Multicultural Drama}

Critics of multiculturalism abound. Timothy Garton Ash suggested recently that, "painful though this will be to those who have expended their academic careers on multiculturalism, the term should be consigned to the conceptual dustbin of history" ([13], p. 33). Variations on this theme have been voiced for some time in intellectual circles, a part of a larger backlash against multiculturalism. One of the most provocative and original critiques is contained in the work of Paul Scheffer. In summarizing his ideas, it is necessary to move from a controversial journalistic essay that appeared in 2000, "The Multicultural Drama" [14] to a scholarly book, Immigrant Nations [15].

The essay begins by asserting that the decision to permit police officers to wear turbans was indicative of cultural confusion. Scheffer paints a pessimistic portrait of what he concludes are failed efforts at the integration of immigrants, with the result being that even after several generations in the Netherlands, the offspring of immigrants lag behind in terms of socioeconomic success. He also faults his fellow citizens for their blind allegiance to political elites who have convinced the public that resurrecting the old pillarization policies for new times is the answer to the issue of immigrant, and particularly, Islamic integration.

That old scheme was predicated on the assumption that "the pillars carried the roof", or in other words, each contributed to national identity and kept the nation whole. The problem with Islam is that it has not liberalized, and in particular resists the idea that religion and politics are separate spheres. The result is that the new instantiation of pillars, now known as multiculturalism, is actually a "house of cards" and an anything goes "cultural of tolerance has now reached its limits" ([15], pp. 4-7). The two problematic manifestations of multiculturalism are that the Dutch no longer appear capable of articulating what their national identity actually means and secondly they are content to remain isolated from newcomers, who in turn are frustrated because of their isolation. The consequence is that the "multicultural drama that is taking place is the biggest threat to social peace" ([15], p. 14).

The book is considerably more nuanced than the article and draws on a century of immigration scholarship. Scheffer is less pessimistic than Caldwell, whom he depicts as being too "gloomy" ([15], p. 34). This does not prevent him from advocating for more restrictive immigration policies. But he describes immigration incorporation as a long and arduous process, one that takes time and occurs over the course of generational succession. He also appreciates that it is a two-way street insofar as the receiving society has to be prepared to embrace the newcomers and to ad- just in some ways to their presence. He understands ambivalence and alienation to be characteristic features of the immigrant experience, and that conflict is both typical and can actually help in the process of inclusion. But he does not share the more optimistic conclusions drawn by scholars such as Leo Lucassen that the evidence to date provides grounds for thinking that immigrant incorporation today is likely to follow the pattern of the past [16].

As such, he is representative of intellectuals who are concerned about national solidarity. The reasons for Scheffer's particular anxiety were evident in the 2000 essay. On the one hand, he is concerned that Islam is resistant to incorporation into secular cultures and democratic polities, but at the same time he sees Islam as a house divided. There is a minority that wants at all costs to avoid the poisoning influences of the West, but there are also reform-minded Muslims. Scheffer voices concern that the reformers have to large extent failed in their efforts to create a liberal Islam capable of fitting into European societies ([15], p. 272).

The Dutch are accused of creating and perpetuating a "culture of avoidance" ([15], pp. 109-140). They avoid addressing what it means to be Dutch in an increasingly diverse society, and they avoid engaging in social relations with newcomers. Here he qualifies his opposition to multiculturalism, contending that he is a critic of its strong version rather than its moderate variants. However, without indicating how he distinguishes the two, he points to his major complaints: multiculturalism encourages cultural relativism, it is backward looking, and it fails to appreciate the significance of citizenship as a unifying status ([15], pp. 197-203).

Critics of Scheffer have suggested that he operates with nostalgia about feeling at home that encourages "us" to define what it means to be Dutch so that "they" can be held to account if they fail in the task of becoming Dutch like us. Robert van Krieken concludes that:

Rather than seeing the Netherlands as an example of the failure of multiculturalism, it shows how the Netherlands has an imperfect take on what it means to be multicultural. Scheffer's book suggests [unintentionally] that the task is not one of abandoning multiculturalism, but of understanding it better, and engaging it with renewed vigor ([17], p. 469).

\section{The State's Role in Muslim Integration}

Caldwell and Scheffer think that states have abrogated their responsibility to integrate immigrants. There are solid empirical grounds to challenge their position. One should note at the outset that despite national differences in church-state relations, there is evidence of convergence in terms of how their respective legal systems address matters associated with the status of religious organizations. As such, religion is viewed, at 
least implicitly, as not simply a right of private individuals, but as a collective right possessed by a community of people sharing a religious faith and committed to structuring their life together according to that faith. Differences, however, persist in defining the proper place of those religious communities in relation to the public sphere. During the initial period of labor migration after World War II, European governments tended to assume that Muslim migrants were temporary workers. As a consequence, those governments did little to facilitate the integration of these newcomers into the receiving societies.

This period was defined by the emergence of what Jonathan Laurence calls "Embassy Islam", which left the role of addressing the religious needs of Muslims in Europe to third parties. Laurence distinguishes two types of Embassy Islam. The first entails a role played by the main sending countries in seeking to maintain connections in order to bolster a commitment to the nation of origin. A state-sanctioned version of Islam was deemed to be a potentially useful antidote to ideological challenges to a regime's legitimacy.

The second type of Embassy Islam is less strictly nationalistic, but instead part of a quest for a panIslamist presence in Europe-with Laurence pointing to the prominence of both Pakistan and Saudi Arabia, "who fashioned their foreign policy in the guise of heirs to the Caliphate" ([18], p. 33). In this variant, the political goals are more ambitious and more potentially challenging to the European host societies. Laurence completes his account by adding yet one more version of Islam in Europe that is not attached to the policies of sending states, the approach advanced by the proponents of Political Islam. This minority, often well-educated exiles who had run afoul of state authorities in the homeland, found an institutional home early on in organizations such as the Muslim Brotherhood and subsequently in an array of other organizations with similar goals. Embassy Islam, especially in its nationalist version, projected itself as an alternative or antidote to Political Islam.

With this contextual backdrop, Laurence chronicles the development since the 1990s of a robust effort on the part of Western European states to actively promote the integration of their Muslim minorities, in part by helping to establish an Islamic institutional presence that contributes to, rather than mitigates against, the incorporation of Muslims into European society ([18], pp. 163-244). He refers to this policy shift as one that is intent on the "domestication" of Islam in Europe, which has been undertaken in order "to fashion national citizens who are less globally interlinked" ([18], p. 11).

In pursuing this objective, he contends that the seven countries with the largest Muslim populations in Europe-Belgium, France, Germany, Italy, the Netherlands, Spain, and the United Kingdom-"have followed remarkably similar pathways to managing their relations with Islam and they display parallel policy devel- opments" ([18], p. 15). Of central importance is the creation of Islam Councils that are intended to shape state-mosque relations and bring both Embassy and Political Islam into the fold, in the process redefining them. Stressing that the outcomes of what has transpired over the two-decade long efforts aimed at domestication are at best imperfect, Laurence nonetheless concludes that such efforts have contributed to advancing a "broader trend toward greater religious freedom and institutional representation for Islam in Europe" ([18], p. 6).

This view is embraced by Christian Joppke and John Torpey in their recent comparative study of the legal integration of Islam in four countries, the two largest nations in continental Europe-France and Germany-and Canada and the United States in North America. They write that, "the institutional accommodation of Islam in Europe has been more successful than [many believe]", and moreover the socioeconomic status of the generational offspring of the immigrants and not Islam is "the root problem" accounting for failures of successful integration. Joppke and Torpey, while agreeing that a convergence along the lines depicted by Laurence is occurring, stress that at the same time nation-specific features remain salient and yield different approaches and outcomes. Comparing France and Germany, they define the former in terms of the "limits of excluding" and the latter in terms of the "limits of including". Put another way, France has a problem with religious freedom, while Germany has a problem with religious equality ([19], p. 11). The French claim that laicité necessitates the exclusion of religion from the public sphere. At the same time, Islam has achieved corporate status in France, placing it in a comparable position to other state-designated religions, and advantageously compared to those organizations designated as cults.

While Germany has not been immune to the issues associated with the veil, it has been less fraught than in France, the most controversial case involving a Muslim teacher. This is a reflection of the fact that religious freedom is not the central problem in Germany. Rather, the central dilemma concerning liberalism and Islam in this case is less about individual religious rights than about the corporate status of Islam. Having a longestablished policy of incorporating Christian denominations, in effect, into the state, to date the state has proven itself to be unwilling to offer Islam similar corporate status. And indeed, it is not simply that Islam has not attained collective parity with the Christian churches, but it found itself in an inferior position to Judaism. This, at least, is the implication to be drawn from the example Joppke and Torpey cite regarding the Jewish, but not Muslim, exemption from the provisions of the 1986 Animal Protection Act. Subsequent judicial decisions have granted in limited circumstances the right of individuals to obtain meat derived from ritual slaughtering practices, but this has been defined in individual and not corporate terms ([19], pp. 63-66). 
One could expand on the differences in state approaches to the integration of Muslims and of Islam by turning to other case studies in Europe and elsewhere, but the point has been made in the French/ German comparison. State approaches will differ depending on the particular interplay of any number of factors, ranging from established legal understandings of church-state relations, the size of the Muslim population, the origins of that population, the prominence of Political Islam, the nation's political landscape (e.g., how significant are right-wing political parties), and public opinion. While considerable attention has been paid to the role played by differing national models, the evidence suggests that within nations, policy approaches are less internally uniform and consistent than some have been led to believe.

\section{Multiculturalism: Official Policy and Unofficial Practice}

Timothy Garton Ash is on firm footing when arguing that multiculturalism has suffered as a consequence of the heated polemics often associated with it, along with its definitional plasticity and vagueness. But this is a problem shared by any number of concepts, including what is generally taken to be the antidote to multiculturalism, namely assimilation. Others have pointed out that many of the more sophisticated discussions of multiculturalism are framed in terms of normative theory, presumably thereby lessening their potential utility as a tool of sociological analysis. If multiculturalism is a social fact, there is a need for a distinctly sociological account of the phenomenon.

Despite the challenges to the articulation of such an account of multiculturalism, promising efforts have been made in developing such a concept. Jeffrey Alexander has done so by treating it as one of three pathways to marginalized minority group incorporation into the societal mainstream ([20], pp. 425-457). Others have done so by focusing less on multiculturalism as a macro-level process and more as a practice entailing claims-making that is amenable to analysis at the micro- or mezzo-levels. Italian theorist Giuseppe Sciortino offered a succinct definition of multiculturalism as entailing "political claims expressed by actors on behalf of a social category" ([21], p. 264). In a recent article on Islamic religious rights in Western Europe, Sarah Carol and Ruud Koopmans employ the concept of claims and counterclaims in examining the conflictual engagements of Muslims and their opponents [22]. It is, in short, possible to view multiculturalism sociologically in two reciprocal ways: (1) as a form of claims-making by minority groups; and (2) as a way that the dominant society and its political system accommodate to and manage diversity.

\subsection{Multiculturalism as Claims-Making}

Peter Kivisto has put flesh on the bones of Sciortino's thesis about multiculturalism as claims-making [23]. He begins by pointing out that claims-making occurs within the public spaces of civil society. The claimsmakers are the more or less legitimate, contested or uncontested spokespersons for a particular type of social category that he refers to as a "community of fate", with the claims being advanced predicated on concerns about the well-being of not only members of that community, but of the community itself-what he refers to as the fate of the community. Claims may be concerned with redistribution, recognition, or some combination of the two. The two audiences to which claims are directed are the public at large and the state, the latter being crucial when claims call for specific legislative actions, court decisions, or policy initiatives.

Five types of political claims can be distinguished: exemption, accommodation, preservation, redress, and inclusion. All are predicated on the idea that the community of fate has what has come to be described as a "right to culture". Very briefly, the five types can be defined in the following way. Exemption refers to a demand for differential treatment of the group based on the conviction that such exemption is necessary if certain group practices deemed essential to cultural identity are to be permitted. Differential treatment takes the form of waiving the application of certain laws, rules, and regulations. Accommodation is similar to exemption in its purpose, but it usually does not require waivers. Rather, it entails finding mutuallyagreeable adjustments, particularly in schools and workplaces that make it possible for individuals to be integrated in the societal mainstream while also being true to their cultural identity.

In both cases, group members themselves are attempting to find ways that they can promote the continuation of their cultural identity and community. Neither calls for the intervention of the state or actors in the larger society to play an active role in maintaining the viability of the group over time. This is precisely what is called for in the third type, preservation. Here the fear is that without the proactive support of the larger society, the future of the community is doomed. Calls to protect minority languages is a case in point, as sometimes the claims-makers call upon the state to fund school instruction in the native language, to create a bilingual society, and so forth. As with the fourth type, redress, preservation tends to be more controversial than the first two types. Redress claims are based on the conviction that grave injustices have been inflicted on the community of fate in the past, injustices that can only be remedied by compensatory actions. These are claims typically made by indigenous peoples and ethnonational minorities-and not by immigrants. This is a reflection of the argument advanced by Kymlicka about which sorts of rights are available to which types of minority groups, with Kymlicka contending that immigrant groups are not able to avail themselves of as robust a range of potential rights as are the other two groups [24]. 
The final claim-inclusion-is one that should surprise critics insofar as they see multiculturalism as encouraging the balkanization of societies. But it is precisely this type of claim that most explicitly reveals the incorporative character of multiculturalism. Within this type, there are two subtypes. The first constitutes a public appreciation of diversity in general and of the particular groups. Whereas this type often takes the form of reaching out or appealing to the public rather than making demands, the second type can involve demands, appeals, or both. What is called for here is an expansion of the boundaries of solidarity by finding room within those boundaries for stigmatized minorities without requiring them to become, in effect, clones of those already inside the boundaries.

Inclusion can entail reconfiguring existing definitions of citizenship and of who is and who is not capable of becoming a citizen on equal terms with others. The American civil rights movement is perhaps the paradigmatic instance of such a call for inclusion. Citizenship provides both a basis for a shared national identity and for expressions of ethnic and religious diversity. Inclusion can also be seen in other arenas of social life. Thus, the perceptual and discursive shift in the middle of the past century from viewing the United States as a Protestant nation to seeing it as a Judeo-Christian one constituted the inclusion of Judaism under the sacred canopy of American religionmade possible by shifts in public opinion.

\subsection{Multiculturalism as Accommodation and Management}

As noted above, the two audiences to which claimsmaking is directed are the public at large and the state. Within both audiences are those who embrace multiculturalism in one version or another as well as those opposed to multiculturalism either in terms of various particulars or writ large, with many being located on a continuum between the two poles. The public is inevitably and invariably divided and public opinion is subject to change, leading to much social scientific research, the purpose of which is to ascertain the precise breakdown of attitudes in a particular country at a particular point in time, as well as identifying the cultural, demographic, economic, ideological, psychological, and related factors shaping particular attitudes. At issue here are attitudes toward minorities. While the above makes clear that multiculturalism's ambit includes indigenous peoples and ethnonational minorities, our concern here is with immigrants and religion, thereby excluding from consideration not only certain groups of claims-makers, but issues related to topics other than religion, such as language.

At issue are not simply attitudes toward members of minority groups, but also attitudes regarding governmental policies designed to remedy the inequalities and marginalization experienced by various minority groups. Analytically separating attitudes toward minority groups from attitudes about policies such as those located under the rubric "multiculturalism" means that there are four possible variations: (1) negative attitudes toward minorities and opposition to policies; (2) negative attitudes toward minorities, but support for policies; (3) positive attitudes toward minorities, but opposition to policies; and (4) positive attitudes toward minorities and support for policies. The first and the fourth appear to need little by way of explanation since they reflect ideological consistency, the first reflecting an exclusionary and intolerant worldview and the latter an inclusionary and tolerant one. In the first category, antipathy toward Muslims is matched by antipathy toward multiculturalism, while in the fourth support for Muslims is coupled with support for multiculturalism. The second possibility strikes me as a null cell.

The third, however, is a possibility, as Paul Sniderman and Louk Hagendoorn indicate in their study of attitudes regarding Dutch multiculturalism. Their contention is that most opponents of multiculturalism are, in fact, tolerant and inclusive. They contend that an unintended consequence of multicultural policies is that they stoke anti-Muslim animus [25]. This conclusion has elicited criticism similar to that evoked by Sniderman's earlier work on affirmative action. It is not necessary to go further into this dispute here, the point being simply that the possibility needs to be taken into consideration.

While there is considerable empirical research on attitudes toward both minorities and multiculturalism -as evident, for example in the Eurobarometer and European Social Survey-there is considerably less research to date on actions and on patterns of majorityminority interaction. Given the rising tide of right-wing extremism and the concerns about violent reactions to minorities, it is understandable-indeed, appropriatethat the research that is conducted on interaction often focuses on the problems of racism and xenophobia. However, what this means is that the mundane patterns of minority-majority relations in everyday life in increasingly diverse societies is in Europe to large extent a field of research is only in its earliest stages of development.

Far more attention has been directed to the actions of states that are increasingly charged with the task of "managing diversity" [26]. State actors in liberal democracies are guided by a complex interplay of ideological or philosophical political commitments and instrumental or pragmatic objectives in contexts shaped by political party rivalries. It is within this general framework that state actors respond to the challenges posed by heterogeneity and inequality-and react to the claims made by minority group spokespersons for recognition or redistribution. While state actors may be motivated by concerns for social justice and equity, they also make decisions predicated on their sense of which policy approaches are most likely to achieve social harmony and equilibrium. One can reasonably assume that states, when they do subscribe to multiculturalism 
in some version or another, are doing so because they have concluded that it is in the interest of their political system as a whole and is a benefit to their society at large [27]. Furthermore, one can expect to find different approaches to multiculturalism predicated on the type of church-state configurations which influence the politics of recognition and differing welfare regimes that impact the politics of redistribution.

\subsection{Quotidian Multiculturalism}

Critics of multiculturalism such as Christian Joppke [28] insist that it represents a dramatic challenge to liberalism, while advocates such as Will Kymlicka [24] are equally insistent that a liberal multiculturalism is possible and viable. Joppke further is convinced that to speak of multiculturalism means you are speaking about the state intervening in ways that are designed to protect diversity. He finds the idea of ordinary people-from both the majority and minority communities-developing relations of mutuality predicated on a recognition and respect for difference to be a "harmless thing" that is somehow beside the point ([29], p. 861). Contrary to his view, the idea that ethnic and religious diversity can exist simultaneously with a shared common identity, whether that be rooted in the nation-state and based on the notion of citizenship, or on the more cosmopolitan ideal of a shared humanity, points to the significance of the realm of civil society. Indeed, not all of the types of claims discussed above necessarily require state action, but rather can often be adequately addressed within the framework of civic society. This is certainly true of accommodation and inclusion.

Whether or not the claims-makers seek state intervention, in making claims they are engaged in civilsociety discourse that can result in negotiated settlements-adaptations-mutually agreed upon by both the religious minority and the host society. We look in the following section at evidence of such multicultural solutions.

\section{Muslim Claims-Making and Negotiated Solutions}

The third implicit question from Caldwell's book concerns indicators of Muslim integration. The results to date are mixed, reflecting the inherent challenges of integrating immigrants and the second generation. We turn to one particular approach to the question that is amenable to the language of claims-making. Ruud Koopmans' Indicators of Citizenship Rights for Immigrants (ICRI) contains 14 of 23 indicators that directly address religious rights, and as the name suggests focuses solely on immigrants:

- allowance of ritual animal slaughtering;

- allowance of the Islamic call to prayer;

- the number of purpose-build mosques with minarets (calculated per 100,000 Muslims);

- the existence of separate cemeteries or cemetery sections for Muslims;

- allowance of burial without coffin;

- the number of state-funded Islamic schools (calculated per 100,000 Muslims);

- the share of costs of Islamic schools that is covered by the state;

- Islamic religious classes in state schools;

- The right of female teachers to wear a headscarf;

- The right of female students in primary and secondary schools to wear a headscarf;

- Islamic religious programs in public broadcasting;

- Imams in the military;

- Imams in prisons;

- The existence and prerogatives of recognized Muslim consultative bodies ([22], p. 172).

Koopmans frames these indicators from the point of view of the state and not as claims-making per se, but if examined from the latter perspective, it is clear that none entail the two most controversial types of claims, preservation and redress. Instead, they would appear to fall into the exemption category (e.g., animal slaughter practices and burial without a coffin) or inclusion (e.g., the public call to prayer, building mosques, imams serving as military and prison chaplains). Many of the claims entail achieving parity with established Christian denominations ([22], p. 167). The particular type of claim at issue for matters related to education is difficult to ascertain because countries have different policies regarding such matters as state funding for religious schools and religious instruction in public schools.

In Rosmarie van den Breemer and Marcel Maussen's comparative analysis of state responses to Muslim claims-making regarding Muslim cemeteries and mosque construction in France and the Netherlands, the authors conclude that despite differing church-state models and differences regarding policies regarding cemetery ownership, both countries have sought to accommodate Muslim claims. They conclude that the relevant question is not "whether governments accommodate Muslim demands for recognition, but which demands are accommodated, in what ways, and for what reasons" ([30], p. 279). The contextspecific ways in which claims are made and responded to has been explored in Sarah Carol and Ruud Koopmans' comparative study of six Western European nations with substantial Muslim populations: France, Germany, the United Kingdom, the Netherlands, Belgium, and Switzerland.

Using a political opportunity model, they contend that those nations that are the most accommodating will provide the space for minority perspectives within the Muslim community to make more "obtrusive" claims. The Netherlands and the United Kingdom are 
defined as more accommodating than the remaining four countries, and thus in the mix of claims, they hypothesize that these two more accommodating nations will experience a higher level of obtrusive claims. The primary example they cite is that of supporting the use of sharia rights in at least some arenas of social life, such as in resolving marital disputes. In this regard, one can point to a similar "obtrusive" claim on the part of Orthodox Jews seeking to use Jewish law in divorce proceedings. While it is true that the percentage of Muslim claims in the Netherlands and the United Kingdom is higher than in the others, it is also true that the overall percentages for all six nations is low. Whereas the overall percentage for the six nations is $1.8 \%$, it is $4.7 \%$ for the Netherlands and $6 \%$ for the United Kingdom. These differences are not that pronounced, given the small percentages in all instances.

At the same time, Carol and Koopmans are no doubt right in concluding that the religious rights of Muslims in the "different countries are likely to settle at diverging equilibria, resulting in a domestication of Islam around nationally specific legal and institutional forms" ([22], pp. 187-188). States react differently depending on their particular understanding of churchstate relations, and in turn Muslims adapt to specific national contexts accordingly. Bowen has illustrated the differential adaptations based on national context by comparing how Muslim leaders have approached the issue of Muslim women seeking a religious divorce in Britain, France, and the United States [31].

It should be remembered that however much Islam has been the focus of attention in Western Europe, religious rights issues have been raised by other religions, as well. Hindu cremation practices and Sikh demands to be exempt from wearing motorcycle helmets to accommodate the turban and to be cleanshaven in work environments involving the handling of food are cases in point. And in all instances the question of the proper role of religion in the public sphere surfaces. Jürgen Habermas writes that, "the liberal state must not transform the requisite institutional separation of religion and politics into an undue mental and psychological burden for those of its citizens who follow a faith". At the same time, he contends that people of faith entering into a pluralist public sphere must engage in a process of translation, one that entails a positive "epistemic" stance toward other religions and worldviews, the autonomy of secular knowledge, and the privileging of secular arguments in the public arena ([32], pp. 9, 14). Habermas harbors skepticism about whether every religion is capable of embracing this stance, a skepticism that informs his attitude toward Islam.
The fear of Islam's critics or skeptics like Habermas is that the basic tenets of the religion preclude adapting such an epistemic stance. Taken to extremes, Islamophobia is preoccupied with Islamist terrorism, with a conviction that Islam and democracy do not mix, and that Islam is bad for women. However, when anxieties about legitimate concerns are transformed into fear, occluded from view is the fact that Islam is not monolithic and immigrants identified as Muslim manifest a wide range of attitudes toward the faithand to faith in general. Fundamentalism-be it Islamic, Christian, Hindu, or other (including fundamentalist atheism)-is an impediment to multicultural incorporation and to the acceptance of religious pluralism. But the religious mainstreams of the major world religions, including Islam, are open to living in a multicultural society. It would appear that at present religion is at some level a barrier to inclusion in Europe, but only to a limited extent and, moreover, it does not necessarily have to be. The process of incorporation has evolved to include not only the immigrant generation, but also the second generation who bring greater acculturation to the receiving society with a willingness to be more overtly critical of both their parents' cultures and that of the settlement society. One significant change underway involves the second generation's separating of sending society culture from religion, thereby seeking to purify the latter. What precisely this will mean is not entirely clear.

While the situation on the ground is complicated, the preponderance of evidence to date provides reasons for guarded optimism about the future. The vast majority of Muslims who have migrated from majority Muslim societies to receiving societies in which they are and will continue to be a minority religion have proven willing to adapt to living in pluralist democracies. And where multicultural policies and practices have created a climate in which differences are not eliminated, but instead respected, a domesticated Islam is taking root. This conclusion does not overlook the problems within immigrant communities -most related to socioeconomic and civic marginalization, residential segregation, and attendant problems such as high unemployment levels, poverty, and crime, but also including troubling Islamist minorities. Nor does it overlook the hostility that Muslim immigrants confront and the unwillingness of many in the receiving societies to extend a neighborly hand. The future will be determined by which of the multiple social imaginaries shaping the cultural dynamics of modern Western societies will in the end win out. The unanswered question is whether it will be shaped by an expansive or a constrictive understanding of collective social life. 


\section{References}

1. Safran W. Islamization in Western Europe: Political Consequences and Historical Parallels. Annals of the American Academy of Political and Social Science. 1986;485(1):98-112.

2. Klausen J. The Cartoons that Shook the World. New Haven, CT, USA: Yale University Press; 2009.

3. European Monitoring Centre on Racism and Xenophobia. Majorities' Attitudes toward Minorities. Available from: http://eumc.eu.int (accessed on 22 March 2010).

4. Pettigrew T. Reactions toward the New Minorities of Western Europe. Annual Review of Sociology. 1998;24(1):77-103.

5. Bleich E. What Is Islamophobia and How Much Is There? Theorizing and Measuring an Emerging Comparative Concept. American Behavioral Scientist. 2011;55(12):1581-1600.

6. Bleich E. Where Do Muslims Stand on EthnoRacial Hierarchies in Britain and France? Evidence from Public Opinion Surveys, 1998-2008. 2009;43(3): 379-400.

7. Mudde C. The Relationship between Immigration and Nativism in Europe and North America. Washington, DC, USA: Migration Policy Institute; 2012.

8. Meer N. Racialization and Religion: Race, Culture, and Difference in the Study of Antisemitism and Islamophobia. Ethnic and Racial Studies. 2013;36(3): 385-398.

9. Bowen JR. Blaming Islam. Cambridge, MA, USA: MIT Press; 2012.

10. Caldwell C. Reflections on the Revolution in Europe: Immigration, Islam, and the West. New York, NY, USA: Doubleday; 2009.

11. Huntington SP. Who Are We? The Challenges to America's National Identity. New York, NY, USA: Doubleday; 2004.

12. Bataille G. Visions of Excess. Minneapolis, MN, USA: University of Minnesota Press; 1985.

13. Ash TG. Freedom \& Diversity: A Liberal Pentagram for Living Together. New York Review of Books. November 2012:33-36.

14. Scheffer P. The Multicultural Drama. Unpublished English translation of Het Multiculturele Drama; 2012.

15. Scheffer P. Immigrant Nations. Cambridge, UK: Polity; 2011.
16. Lucassen L. The Immigrant Threat: The Integration of the Old and New Migrants in Western Europe since 1850. Urbana, IL, USA: University of Illinois Press; 2005.

17. van Kreiken R. We Have Never Been Multicultural. Contemporary Sociology. 2012;41(4):466-469.

18. Laurence J. The Emancipation of Europe's Muslims: The State's Role in Minority Integration. Princeton, NJ, USA: Princeton University Press; 2012.

19. Joppke C, Torpey J. Legal Integration of Islam: A Transatlantic Comparison. Cambridge, MA, USA: Harvard University Press; 2013.

20. Alexander J. The Civil Sphere. New York, NY, USA: Oxford University Press; 2006.

21. Sciortino G. From Heterogeneity to Difference? Comparing Multiculturalism as a Description and as a Field for Claim-Making. Comparative Social Research. 2003;22:263-285.

22. Carol S, Koopmans R. Dynamics of Contestation over Islamic Religious Rights in Western Europe. Ethnicities. 2013;13(2):165-190.

23. Kivisto P. We Really Are All Multiculturalists Now. The Sociological Quarterly. 2012;53(1):1-24.

24. Kymlicka W. Multicultural Citizenship. New York, NY, USA: Oxford University Press; 1995.

25. Sniderman P, Hagendoorn L. When Ways of Life Collide: Multiculturalism and Its Discontents in the Netherlands. Princeton, NJ, USA: Princeton University Press; 2007.

26. Rodriguez-Garcia D. Beyond Assimilation and Multiculturalism: A Critical Review of the Debate on Managing Diversity. Journal of International Migration and Integration. 2010;11(3):251-271.

27. Kivisto P. Multiculturalism in a Global Society. Malden, MA, USA: Blackwell; 2002.

28. Joppke C. Citizenship and Immigration. Cambridge, UK: Polity; 2010.

29. Joppke C. Rejoinder. Ethnicities. 2012;12(6): 859-863.

30. van den Breemer R, Maussen M. On the Viability of State-Church Models: Muslim Burial and Mosque Building in France and the Netherlands. Journal of Immigrant \& Refugee Studies. 2012;10(3):279-298.

31. Bowen J. Islamic Adaptations to Western Europe and North America: The Importance of Contrastive Analyses. American Behavioral Scientist. 2011;55(12): 1601-1615.

32. Habermas J. Religion in the Public Sphere. European Journal of Philosophy. 2006;14(1):1-25. 